\title{
The effects of biochar and inorganic amendments on soil remediation in the presence of hyperaccumulator plant
}

\author{
Zahra Derakhshan Nejad ${ }^{1} \cdot$ Myung Chae Jung ${ }^{2}$
}

Received: 3 April 2017/Accepted: 12 October 2017/Published online: 20 October 2017

(c) The Author(s) 2017. This article is an open access publication

\begin{abstract}
Industrialization advances have led to an increase soil contamination by heavy metals. Among different technologies, in situ stabilization of metals combined with revegetation attracted attention. Therefore, this study aimed at comparing effects of biochars [rice husk biochar (RHB), maple leaves biochar (MLB)] and common inorganic amendments [red mud (RM), and steel slag (SS)] at different rates $(0.5,1$, and $2 \% \mathrm{w} / \mathrm{w})$ on leaching, and phytoavailability of metals (assessed using mustard green "Brassica juncea"). Soil $\mathrm{pH}$ in treated soils significantly $(p<0.01)$ increased, with the optimal $\mathrm{pH}$ ranges for plant growth observed in biochar-treated soils. The leaching of $\mathrm{Cd}, \mathrm{Cu}, \mathrm{Pb}$, and $\mathrm{Zn}$ through soil significantly $(p<0.05)$ decreased in treated soils. Plant uptake and accumulation of $\mathrm{Cd}, \mathrm{Cu}, \mathrm{Pb}$, and $\mathrm{Zn}$ decreased by 79-66, 13-19, 87-86, and $37-36 \%$ in RHB- and MLB-treated soils, respectively. Sequential extraction analysis pointed out that the major stabilization mechanism for metals using biochars involved the formation of organic and carbonate bonds, while for RM and SS was believed to involve the formation of inner sphere complexes with Fe/Al (hydr)oxides. The plant available fractions for $\mathrm{Cd}$ were generally higher than those for others. Overall, high dosage addition (2\%) of each amendment offered the best compromise as it successfully reduced both leaching and phytoavailability of metals. Using MLB for the first time, showed promising results to immobilize metals with an increase in plant biomass.
\end{abstract}

Zahra Derakhshan Nejad

derakhshan_10z@yahoo.com

1 Department of Earth System Sciences, Yonsei University, Seoul 03722, South Korea

2 Department of Energy and Mineral Resources Engineering, Sejong University, Seoul 143-747, South Korea
Keywords Biochar - Immobilization - Metal leaching Soil amendments · Phytoavailability

\section{Introduction}

Among the hazardous contaminants which are found in the environment, heavy metals gained the majority of concerns. Several human activities have the potential of producing heavy metals as side effects. Movement of such contaminants into surrounding areas in form of dust, leachates through the soil, and spreading of sewage sludge is a common example of contamination of the ecosystems [1]. Mining and corresponding activities are recognized as point sources of toxic element pollution that can damage the surface environment [2]. High concentrations of toxic metals can be found in and around abandoned metal mines due to discharge and dispersion of mine wastes [3].

Various innovative techniques are devised to make reclamation such contaminated sites by economic means, but most of them are costly and do not reach their optimum performance. One of the promising remediation methods is solidification and stabilization (S/S) [4]. If the soil immobilization technique is employed, simplicity and rapidity (besides high public acceptability) will be achieved. This method is relatively inexpensive, while covering a broad spectrum of inorganic pollutants [5].

During the process of immobilization, heavy metals in soils are removed using amendments from soil solution either through adsorption, complexation, and precipitation reactions, thereby rendering the metal(loid)s unavailable for human and plant uptake and leaching to groundwater [6]. One of these promising amendments is biochar, which is a porous, carbonaceous product obtained from the pyrolysis of organic materials. Numerous materials can be 
used as feedstock. Rice husk, as one of the major crop residues, showed a great ability to remove various heavy metal pollutants and increase in crop yield [7-11]. Every autumn across the world, diminishing daylight hours and falling temperatures induce trees to shed leaves in billions of tons. One of the prevalent trees worldwide is the maple tree which is easily accessible. Hence, fallen maple leaves might be a promising feedstock to use as soil amendment. However, the application of biochars on immobilization of heavy metals has not been systematically investigated to any extent [12]. Red mud, a reddish-brown colored solid waste produced from the aluminum industry, is known as a cheap adsorbent for the removal of toxic metals. Lee et al. [13] reported that adding red mud as a good adsorbent for the adsorption of $\mathrm{Cd}, \mathrm{Pb}$, and $\mathrm{Zn}$ significantly decreased the amount of soluble and extractable heavy metals in soil. Moreover, steel slag is considered as an appropriate soil agent to reduce the migration of toxic elements to plants and groundwater [14, 15].

In general, the immobilization of metals by amendments is frequently combined with the revegetation of contaminated soil to improve the level of soil remediation. The establishment of a suitable plant on the soil is helpful in preventing the dispersion of contaminants through erosion, runoff, and percolation while increasing biodiversity as well as being aesthetically pleasant [16-18]. Brassica juncea is a species of mustard plant which is used in phytoremediation to remove heavy metals. Thus, implementing a phytoremediation strategy on contaminated soils requires a serious evaluation of the effects of amendments on metal phytoavailability [19]. Despite the fact of phytoavailability and leachability of heavy metals in contaminated soils, evaluation of the simultaneous effects of biochars and inorganic amendments combined with revegetation on immobilization of heavy metals has considerably been the subject of only limited studies [20].

Therefore, this study was aimed to investigate the effects of biochars including rice husk biochar (RHB), maple leaves biochar (MLB), and inorganic amendments including red mud (RM), and steel slag (SS) on the immobilization, phytoavailability, and leachability of heavy metals through soil. Sequential extraction method was applied to distinguish the differences in metal fractionations after using amendments.

\section{Materials and methods}

\section{Preparing soil samples and amendments}

Soil was collected from agricultural land adjacent to the abandoned Geopung Mine in Okcheon County in South Korea $\left(127^{\circ} 44^{\prime} 13.60^{\prime \prime}\right.$ and $\left.316^{\circ} 19^{\prime} 48.20^{\prime \prime} \mathrm{N}\right)$. About $150 \mathrm{~kg}$ of soil surface $(15-20 \mathrm{~cm})$ from Geopung Mine area were collected using shovels. The samples were put into plastic bags and transported to the laboratory. Then, samples were dried at ambient temperature $\left(23^{\circ} \mathrm{C}\right)$ for 3 days and sieved through a $2 \mathrm{~mm}$ mesh.

To produce amendment, white rice husk was purchased from a local mill, thoroughly washed using deionized water, dried, and then ground. Fallen maple leaves were collected from the piles near the trees in the study area in Seoul. Sampled maple leaves thoroughly washed and dried in oven $\left(40^{\circ} \mathrm{C}\right)$ for 5 days and finely ground. To obtain alkaline biochars, dry-pyrolysis process was made at $550{ }^{\circ} \mathrm{C}$ temperatures through a residence time of $45 \mathrm{~min}$ inside an anaerobic furnace (WiseTherm(R) FT Programmable Tube Furnaces) under an $\mathrm{N}_{2}$ environment. In addition, RM and SS by-products coming from alumina smelters and steel work companies, respectively, were purchased to use as inorganic amendments. Afterward, all amendments were ground to obtain all particles in size of $<74 \mu \mathrm{m}$ to increase their specific surface area [21].

\section{Characterization of soil and amendments}

Soil texture was measured using the hydrometer method [22]. Soil and amendment $\mathrm{pH}$ values were determined using 1:5 ratio of samples and distilled water, respectively [23]. Cation exchange capacity (CEC) of each amendment and initial soil was measured using $1 \mathrm{M}$ sodium acetate, ethanol 95\%, and $1 \mathrm{M}$ ammonium acetate, respectively [24]. Total concentrations of heavy metals $(\mathrm{Cd}, \mathrm{Cu}, \mathrm{Pb}$, and $\mathrm{Zn}$ ) in soil and inorganic amendments were determined by digesting with aqua regia and analyzed by Atomic Adsorption Spectrometry (AAS; AA240, Varian, Australia) [25]. Concentration of heavy metals in biochars was measured using the USA EPA method No. 1311. The specific surface area (SSA) of all sorbents was measured by $\mathrm{N}_{2}$ adsorption using the BET surface area of sorbents on a Tristar 3000 by BET method [26]. In the current study, five steps (operationally defined) of sequential extraction based on Tessier et al. [27] as an approach to evaluate metal distribution into different chemical forms were investigated before and after mixing soil with amendments.

Several analyses, including use of scanning electron microscopy (SEM), X-ray diffraction (XRD), and X-ray florescence (XRF) were conducted to characterize the properties of the amendments. To determine chemical compositions of soil amendments, XRF analysis was accomplished. To identify the mineralogy properties of amendments, XRD analysis was carried out. By using SEM Coxem S-100 production microscope, the morphology of each amendment was examined. 


\section{Pot experiment}

A greenhouse study was carried out to investigate the effect of amendments on heavy metal leaching and phytoavailability. A leaching pot $(10 \mathrm{~cm}$ height and $15 \mathrm{~cm}$ width) was used for experiments. The pots were filled with a mixture of contaminated soil and washed sand with the ratio of 3:1, regarding to prevent soil compaction. Based on the previous research results [28, 29], different ratios of soil amendments $(0.5,1$, and $2 \%$ dry mass $)$ were applied as different treatments. The amendments were thoroughly mixed with soils to obtain homogeneity were then equilibrated for 8 weeks. A control treatment following the same procedure was also prepared, but without adding amendment. All treatments were performed in three replicates. After finishing the period of equilibration, premature mustard green (21 days) was transplanted in each pot separately. Pots were irrigated four times a week with deionized water (DIW). On irrigation days, each pot received the same amount of DIW (100 ml each time).

\section{Leachate sampling}

At each date of leachate collection, the solution was collected by the PET clear plastic bottles. A small aliquot was then set aside for $\mathrm{pH}$ determination and the remaining solution was filtered at Whatman $0.50 \mu \mathrm{m}$. Samples were put into refrigerator before measurement. Concentrations of $\mathrm{Cd}, \mathrm{Cu}, \mathrm{Pb}$, and $\mathrm{Zn}$ in the leachates were measured by AAS.

\section{Phytoavailability}

To investigate the effect of each treatment on the phytoavailability of contaminants, mustard green was chosen as strong hyperaccumulator plant. Every 20 days, equal number of plant leaves was taken from each pot. The remaining plant leaves were harvested 8 weeks after sowing. Samples were rinsed with DIW and dried in oven at $40{ }^{\circ} \mathrm{C}$ for 5 days. Plant samples were digested in hot $\mathrm{HNO}_{3}$, and the resultant solutions were filtered at cellulose acetate syringe filters. Finally, concentrations of target metals were measured using AAS.

\section{Statistical analyses}

As treatments performed triplicate, all values of heavy metals in soils were reported as the mean values of three samples. Any significant difference among treatments was determined by one-way analysis of variance (ANOVA). Pearson's correlation coefficient $(r)$ was purposed to determine the relationships between different treatments and their $\mathrm{pH}$. Three levels of significance were considered: $p<0.1, p<0.05$ and $p<0.01$. Statistical analyses were carried out using SPSS 16 on Windows 7.

\section{Results and discussion}

\section{Physical and chemical properties of original soil and amendments}

The properties of the original soil are presented in Table 1 . The soil was almost neutral $\mathrm{pH}(6.69)$ and was contaminated by heavy metals $(1.0,54.9,74.4$, and $291 \mathrm{mg} / \mathrm{kg}$ for $\mathrm{Cd}, \mathrm{Cu}, \mathrm{Pb}$, and $\mathrm{Zn}$, respectively). According to the average values reported on Korean cultivated soils, the obtained results for organic matter $(0.59 \%)$ and clay content $(11.36 \%)$ were relatively low [30]. The value of total $N(0.04 \%)$ indicated that soil had poor nutrient. Hence, to achieve optimal plant growth, additional nutrient supplement was required. In addition, soil showed relatively low value of CEC (7.6 meq/100 g).

As is shown in Table 1, heavy metal concentrations in the amendments (except $\mathrm{Zn}$ content in RM and SS) were low. Hence, the amount of each metal added to the soil through aforementioned applied ratio of amendments is negligible. All amendments showed slightly to highly alkaline $\mathrm{pH}$ for RHB to SS, respectively. Among amendments, the SS indicated the highest value for $\mathrm{pH}$ (11.83). However, MLB showed higher $\mathrm{pH}$ compared with RHB ( 8.89 vs. 7.86 ). These values for $\mathrm{pH}$ may imply potential for an increase in soil $\mathrm{pH}$ when incorporated into soil. The specific surface area (SSA) of each amendment exhibited relatively high value, where more available sites on the surface caused more metal ion adsorption [31]. The highest SSA was observed for RM followed by SS. The other important factors which potentially affected on metal sorption on the surface amendments were high CEC of each amendment $(20,22,45.24$, and $25.22 \mathrm{meq} / 100 \mathrm{~g}$ for RHB, MLB, RM, and SS, respectively). Biochars showed high content of $\mathrm{P}$ and $\mathrm{K}$ which are fundamentally influence on plant growth. Content of organic matter (OM\%) was meaningfully more in both biochar than RM and SS.

\section{XRF, XRD, and SEM analysis results}

Chemical composition of the amendments determined by XRF analyzer already reported in Derakhshan Nejad et al. [32]. The main content of RHB was $\mathrm{SiO}_{2}(61 \%)$ which can induce ion-exchange reaction and metal stabilization as well, while $\mathrm{CaO}$ was the main content in MLB. Indeed, high content of $\mathrm{CaO}$ in biochar was supposed to have high adsorption efficiency of metals through soil. The main chemical compositions of RM were $\mathrm{Al}_{2} \mathrm{O}_{3}, \mathrm{Fe}_{2} \mathrm{O}_{3}, \mathrm{SiO}_{2}$, and $\mathrm{Na}_{2} \mathrm{O}$. Results of XRF for SS indicated similar 
Table 1 Physiochemical properties of the original soil and amendments

\begin{tabular}{|c|c|c|c|c|c|c|c|c|c|c|c|c|}
\hline $\begin{array}{l}\text { Name of } \\
\text { samples }\end{array}$ & $\mathrm{pH}$ & $\begin{array}{l}\mathrm{Cd}(\mathrm{mg} / \\
\mathrm{kg})\end{array}$ & $\begin{array}{l}\mathrm{Cu}(\mathrm{mg} / \\
\mathrm{kg})\end{array}$ & $\begin{array}{l}\mathrm{Pb}(\mathrm{mg} / \\
\mathrm{kg})\end{array}$ & $\begin{array}{l}\mathrm{Zn}(\mathrm{mg} / \\
\mathrm{kg})\end{array}$ & $\begin{array}{l}\text { T-P (mg/ } \\
\mathrm{kg})\end{array}$ & $\begin{array}{l}\mathrm{T}-\mathrm{N} \\
(\%)\end{array}$ & $\begin{array}{l}\mathrm{OM} \\
(\%)\end{array}$ & $\begin{array}{l}\mathrm{K}(\mathrm{mg} / \\
\mathrm{kg})\end{array}$ & $\begin{array}{l}\text { CEC (meq/ } \\
100 \mathrm{~g})\end{array}$ & $\begin{array}{l}\text { SSA } \\
\left(\mathrm{m}^{2} / \mathrm{g}\right)\end{array}$ & Texture \\
\hline Original soil & 6.69 & 1.00 & 55 & 74.4 & 291 & 607 & 0.04 & 0.59 & ND & 7.60 & ND & $\begin{array}{l}\text { Loamy } \\
\text { sand }\end{array}$ \\
\hline RHB & 7.86 & 0.09 & 18 & 0.50 & 48 & 48,714 & 3.30 & 48.76 & 2701 & 20.00 & 7.36 & ND \\
\hline MLB & 8.89 & 0.39 & 5 & 0.50 & 38 & 1379 & 0.54 & 21.00 & 2520 & 22.00 & 12.20 & ND \\
\hline RM & 10.73 & ND & 15 & 48.00 & 131 & 280 & 0.01 & 0.50 & 48 & 45.24 & 44.13 & ND \\
\hline SS & 11.83 & ND & 18 & 18.00 & 442 & 4983 & 0.01 & 0.89 & 169 & 25.22 & 17.86 & ND \\
\hline
\end{tabular}

$R H B$ rice husk biochar, $M L B$ maple leaves biochar, $R M$ red mud, $S S$ steel slag, $N D$ not detected, $S S A$ specific surface area

chemical compositions to RM, given that $\mathrm{SiO}_{2}$ allocated main composition of $\mathrm{SS}$ followed by $\mathrm{Al}_{2} \mathrm{O}_{3}$.

The XRD analysis patterns of amendments are presented in Fig. 1. A broad XRD peak centered at $2 \theta=22.5$ showed amorphous (noncrystalline) silica, as a major constituent of RHB, which was attributed to the presence of disordered cristobalite and amorphous carbon, as well (Fig. 1a) [33-35]. Sharp peaks in the diffractogram of MLB indicated that calcite $\left(\mathrm{CaCO}_{3}\right)$ and whewellite $\left(\mathrm{Ca}\left(\mathrm{C}_{2} \mathrm{O}_{4}\right) \cdot \mathrm{H}_{2} \mathrm{O}\right)$ were consistent with its pyrolysis temperature (Fig. 1b). This type of structure can be highly efficient to remove heavy metal ions from contaminated soils. Actually, the adsorption mechanism in this type of structure is that either $\mathrm{Ca}^{2+}$ ions are replaced by heavy metal ions or heavy metal ions are adsorbed at larger space [36]. However, the element analysis and phase characterization of RM were reported several times, but the results of the composition of RM showed unsymmetrically [37-39]. In this study, the XRD patterns of the RM showed the presence of calcite $\left(\mathrm{CaCO}_{3}\right)$, hematite $\left(\mathrm{Fe}_{2} \mathrm{O}_{3}\right)$, quartz $\left(\mathrm{SiO}_{2}\right)$, boehmite $(\gamma-\mathrm{AlO}(\mathrm{OH}))$, and zeolite $(\mathrm{ZSM}-5)$ as the main phases. The results of XRD indicated that the main phases in the SS were siderotil $\left(\mathrm{FeSO}_{4} \cdot 5 \mathrm{H}_{2} \mathrm{O}\right)$, quartz $\left(\mathrm{SiO}_{2}\right)$, calcite $\left(\mathrm{CaCO}_{3}\right)$, albite $\left(\mathrm{NaAlSi}_{3} \mathrm{O}_{8}\right)$, illite $\left(\mathrm{KH}_{3}\right.$ $\mathrm{O}) \mathrm{M}$, and magnetite $\left(\mathrm{Fe}_{3} \mathrm{O}_{4}\right)$. Results demonstrated obviously different mineral compositions among all amendments.

The SEM images for all amendments are shown in Fig. 2. The combination of SEM characterization with XRD and XRF can represent comprehensive understanding of physical and microstructural performance of soil amendments. The results of SEM revealed that all amendments included pores (Fig. 2), which were consistent with relatively high SSA (Table 1). However, biochars showed SSA smaller than RM and SS. However, internal porous structure, particles shape, and high negative charge on the biochar surfaces corresponding to the carbonaceous structure of them might be the main reason of their high performance in cation adsorption. These results matched with the results reported by Prakongkep et al. [40]. The porosity provided by the plant cell structure led to the very large SSA performance and high chemical activity of biochars [41]. Poor crystalline silica was a major constituent of RHB. According to the results reported by Park et al. [42], much of the silica was observed in the outer epidermis cells and concentrated in hair- and dome-shaped protrusions and also as dispersed silica inside the husk (Fig. 2a). However, crystalline calcite was observed as the main content in and outside of the MLB cells (Fig. 2b). As shown in Fig. 2c, the RM had relatively loose microstructures and high porosity. The particles of RM were more dispersive. On the contrary, SS was able to easily gather and formed a cluster (Fig. 2d). The SS particles surrounded to angular shapes. Distinct roughness and edges were dominant in angular and bulky particles. Most of its particles examined by SEM had rough surface textures.

\section{Effect of treatments on $\mathrm{pH}$}

After adding amendments into the soil, $\mathrm{pH}$ increased significantly $(p<0.01$, Table 2). Soil $\mathrm{pH}$ increased from 6.69 to approximately $7.37,7.55,8.47$, and 8.58 in RHB, MLB, RM, and SS with $2 \%$ amended soils, respectively. As shown in Table 3, almost all treatments indicated significant difference in changing soil $\mathrm{pH}$ values, compared with control and each other, as well. As an exception, RHB treatments (1 and 2\%) and MLB treatment (2\%) showed no significant differences with RM treatments (1 and 2\%) and SS treatment (2\%), respectively. In addition, results showed positive Pearson's correlation coefficient pattern of changing $\mathrm{pH}$ among all treatments and control soil. That means $\mathrm{pH}$ in treated/nontreated soils changed differently, but in a similar direction. In general, there was no high correlation coefficient among $\mathrm{pH}$ values observed in different treatments during the 60 days of experiment. 

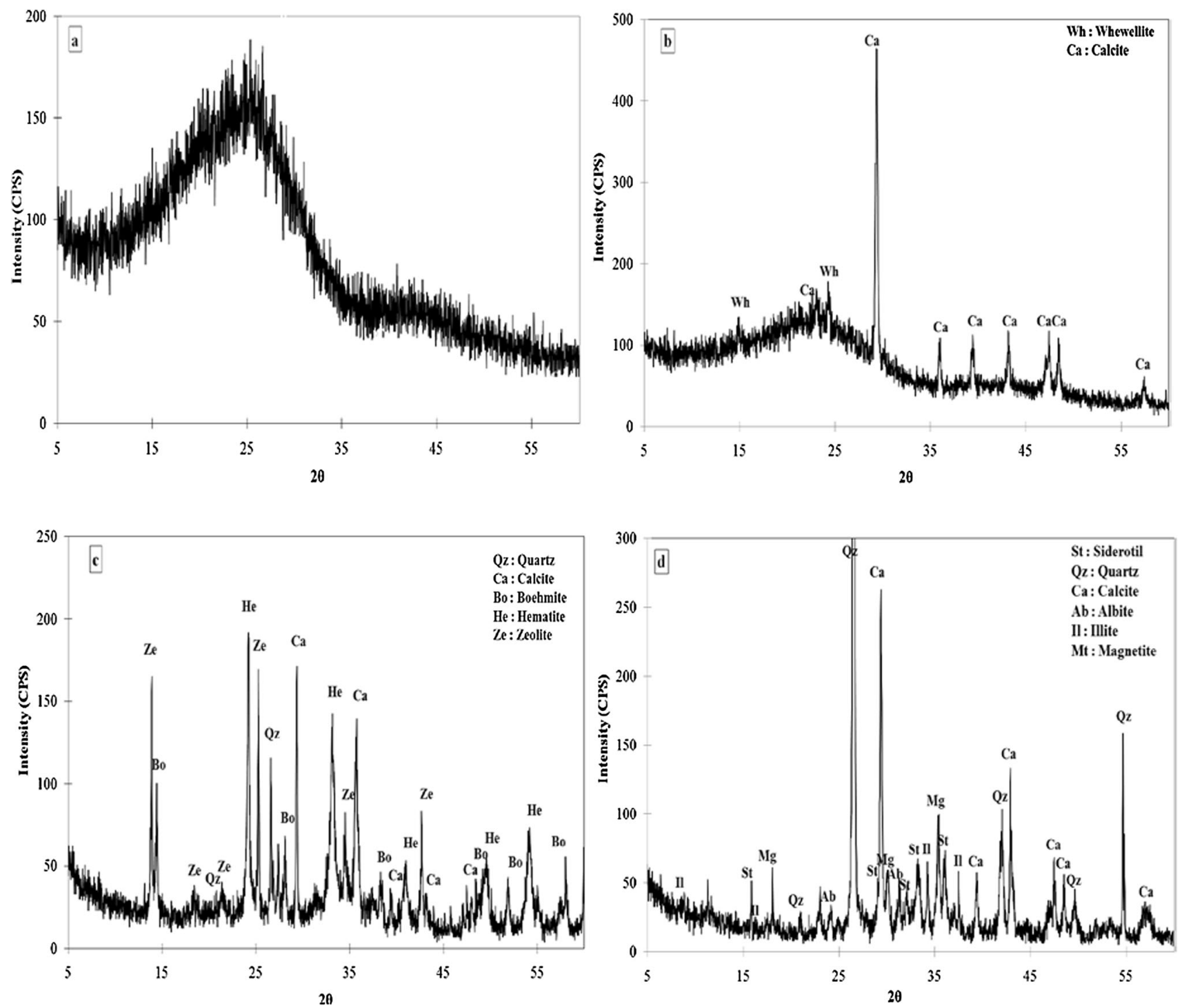

Fig. 1 XRD results of soil amendments: (a) rice husk biochar, (b) maple leaves biochar, (c) red mud, and (d) steel slag

\section{Effect of various treatments on metal leaching}

Mean concentration of metals in leachates for all treatments is presented in Fig. 3. It is worth to note that low initial concentration of $\mathrm{Cd}$ in soil caused an observation of low content of $\mathrm{Cd}$ in leachates. Nevertheless, adding all amendments at the rate of $2 \%$ after 60 days significantly $(p<0.05)$ reduced $\mathrm{Cd}$ concentration in leachate (Fig. 3a). The main reason may attribute to the surface complexation with silicate materials and calcium carbonate that presented in the structure of biochars. In general, forms of the carbonate and oxidate of $\mathrm{Cd}$ are insoluble fraction in soil. Therefore, all amendments showed ability for reducing $\mathrm{Cd}$ leaching through soil subsequent of reduction in $\mathrm{Cd}$ solubility. Compared with control soil, $\mathrm{Cu}$ concentration in leachates considerably decreased for all treatments $(p<0.05)$. However, there was no statistically significant difference between each treatment in reducing $\mathrm{Cu}$ leaching, except $\mathrm{SS}$ at the rate of $2 \%$ (Fig. $3 \mathrm{~b}$ ). The main reason related to the high $\mathrm{pH}$ and low content of organic carbon in $\mathrm{SS}$, which caused more $\mathrm{Cu}$ immobilization in soil. Concentration of $\mathrm{Pb}$ in leachates was decreased significantly $(p<0.05)$ in all treatments except RHB and MLB treatments when $0.5 \%$ from each one was applied (Fig. 3c). Over the course of the experiment, $\mathrm{Zn}$ concentration in leachates from the treated soils significantly $(p<0.05)$ decreased (Fig. 3d). It is notable that RM treatment $(2 \%)$ effectively reduced concentration of $\mathrm{Zn}$ in leachate. 

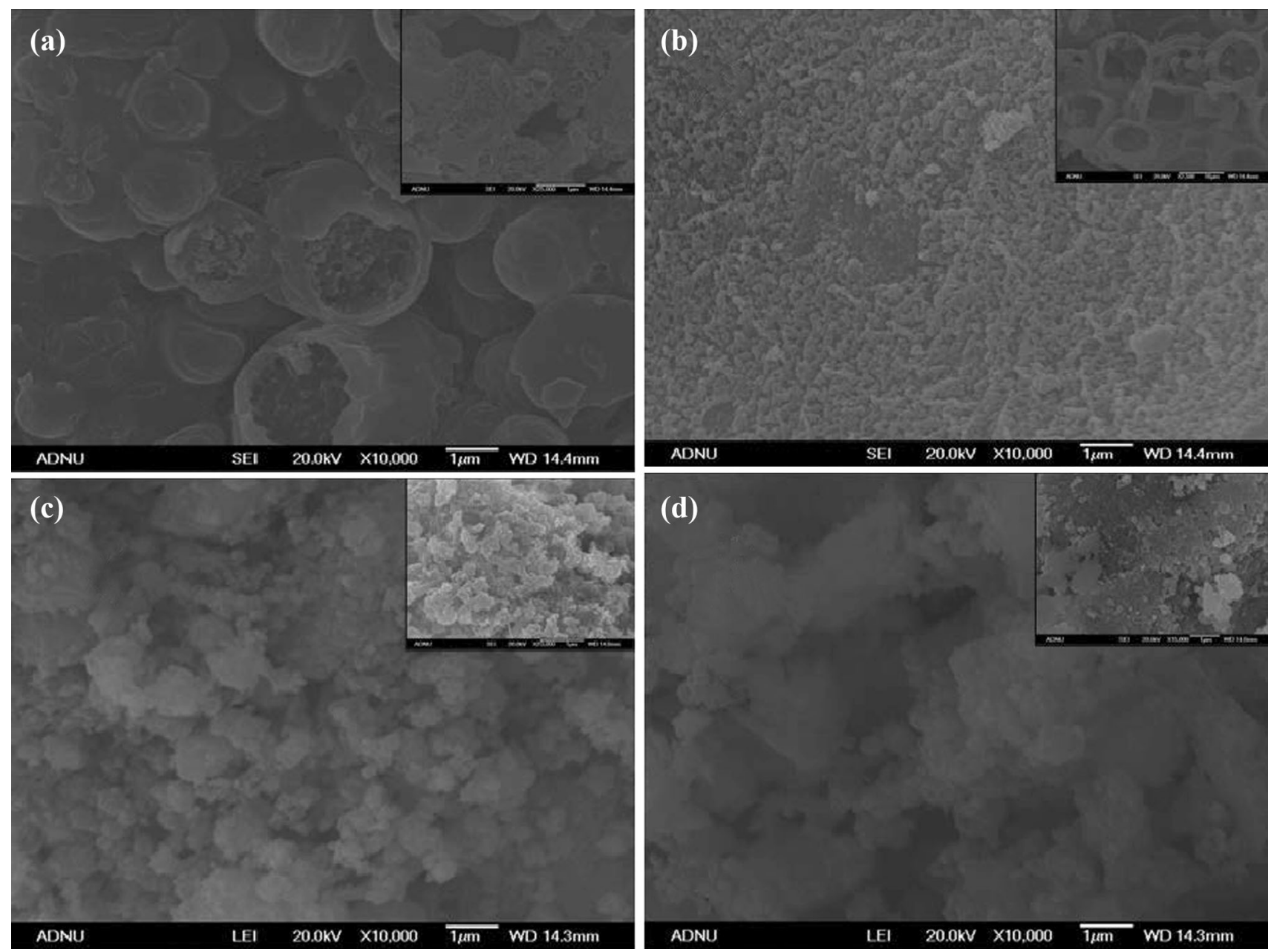

Fig. 2 Scanning electron microscopy images of amendments: (a) rice husk biochar, (b) maple leaves biochar, (c) red mud, and (d) steel slag

\section{Phytoavailability of metals}

The concentrations of metals in plant tissues showed different results among amendments. In general, soil phytoavailable metal pools following amendments application was decreased for all heavy metals in mustard green leaves (Fig. 4). After plant harvesting (60th day of transplanting), mean concentrations of $\mathrm{Cd}, \mathrm{Cu}, \mathrm{Pb}$, and $\mathrm{Zn}$ in leaves of mustard green grown in the nontreated soil (control) were, $0.85,5.73,1.12$, and $88.16 \mathrm{mg} / \mathrm{kg}$, respectively (Fig. 4). Compared with control, concentration of $\mathrm{Cd}$ in plant leaves in all treatments (at the rate of the 2\%) significantly $(p<0.05)$ decreased (Fig. 4a). Plant uptake and accumulation of Cd was decreased by 79, 66, 73, and 53\% in RHB, MLB, RM, and SS treatments, respectively. Results indicated that the addition of amendments in different application rates only slightly reduced the concentration of $\mathrm{Cu}$ in plant leaves. Plant accumulation of $\mathrm{Cu}$ decreased by 13, 19, 13, and 25\% in RHB-, MLB-, RM-, and SS-treated soils, respectively. Considering the best efficiency in reduction of $\mathrm{Cu}$ uptake by plant, the application of SS in mixing ratio of $2 \%$ was observed (Fig. 4b).

All treatments were effective in decreasing the concentration of $\mathrm{Pb}$ in aerial parts of mustard green to compare with the control, with the maximum efficiency being observed for SS and RHB treatments in an application ratio of 1 and $2 \%$ (Fig. $4 \mathrm{c}$ ). For $\mathrm{Pb}$, plant accumulation decreased by $87,86,87$, and $92 \%$ in RHB, MLB, RM, and SS, respectively. On the contrary, the addition of SS just slightly decreased $\mathrm{Zn}$ accumulation in plant leaves compared with other treatments. Indeed, both biochar (RHB and MLB) application caused a significant reduction in plant $\mathrm{Zn}$ uptake (Fig. 4d). Plant uptake and accumulation of $\mathrm{Zn}$ decreased by 37, 36, 31, and $18 \%$ in RHB, MLB, RM, and SS treated soils, respectively. However, mustard green was a hyperaccumulator but using amendment meaningfully decreased plant uptake of metals. For these metals, the lower metal accumulation by mustard green was attributed principally to increase in $\mathrm{pH}$ and $\mathrm{CEC}$ which 
Table 2 Overview of significantly differences and Pearson's correlation coefficients $(r)$ among different amendments application ratio and treated/nontreated soils $\mathrm{pH}$ values

\begin{tabular}{|c|c|c|c|c|c|c|c|c|c|c|c|c|}
\hline \multirow{2}{*}{$\begin{array}{l}\text { Soil } \mathrm{pH} \text { under different } \\
\text { treatments }\end{array}$} & \multicolumn{3}{|c|}{ RHB (\%) } & \multicolumn{3}{|c|}{$\operatorname{MLB}(\%)$} & \multicolumn{3}{|c|}{$\mathrm{RM}(\%)$} & \multicolumn{3}{|l|}{ SS (\%) } \\
\hline & 0.5 & 1 & 2 & 0.5 & 1 & 2 & 0.5 & 1 & 2 & 0.5 & 1 & 2 \\
\hline \multicolumn{13}{|l|}{ Control (\%) } \\
\hline 0 & $0.6^{* * *}$ & $0.5 * * *$ & $0.5 * * *$ & $0.7 * * *$ & $0.5 * * *$ & $0.3 * * *$ & $0.3 * * *$ & $0.3 * * *$ & $0.1 * * *$ & $0.5 * * *$ & $0.6^{* * *}$ & $0.5^{* * * *}$ \\
\hline \multicolumn{13}{|l|}{ RHB (\%) } \\
\hline 0.5 & 1 & $0.8^{* * *}$ & $0.8^{* * *}$ & $0.4 * *$ & $0.4 * *$ & $0.2 * * *$ & $* * *$ & $0.1 * * *$ & $* * *$ & $0.2 * *$ & $0.2 * * *$ & $0.2 * * *$ \\
\hline 1 & & 1 & $0.9 * * *$ & $0.4 * * *$ & $0.2 * * *$ & 0.2 & $* * *$ & - & $* * *$ & $0.1 * * *$ & $0.1^{*}$ & $0.1^{*}$ \\
\hline 2 & & & 1 & $0.4 * * *$ & $0.2 * * *$ & 0.2 & $* * *$ & - & $* * *$ & $0.1 * * *$ & $0.1 * *$ & - \\
\hline \multicolumn{13}{|l|}{$\operatorname{MLB}(\%)$} \\
\hline 0.5 & & & & 1 & $0.5 * * *$ & $0.4 * * *$ & $0.1 * * *$ & $0.2 * * *$ & $0.1 * * *$ & $0.3 * * *$ & $0.4 * * *$ & $0.3 * * *$ \\
\hline 1 & & & & & 1 & $0.8 * * *$ & $0.2^{*}$ & $0.2 * * *$ & $0.3 * * *$ & 0.3 & $0.3 * * *$ & $0.3 * * *$ \\
\hline 2 & & & & & & 1 & $* * *$ & - & $0.2 * * *$ & $0.1 * * *$ & $0.2 * *$ & - \\
\hline \multicolumn{13}{|l|}{ RM (\%) } \\
\hline 0.5 & & & & & & & 1 & $0.6 * * *$ & $0.3 * * *$ & $0.3 * * *$ & 0.4 & $0.3 * * *$ \\
\hline 1 & & & & & & & & 1 & $0.2 * * *$ & $0.6 * * *$ & $0.3 * * *$ & $0.6^{*}$ \\
\hline 2 & & & & & & & & & 1 & $0.20 * * *$ & $0.3 * * *$ & $0.3 * * *$ \\
\hline \multicolumn{13}{|l|}{ SS (\%) } \\
\hline 0.5 & & & & & & & & & & 1 & $0.8 * * *$ & $0.8 * * *$ \\
\hline 1 & & & & & & & & & & & 1 & $0.8 * * *$ \\
\hline 2 & & & & & & & & & & & & 1 \\
\hline
\end{tabular}

$R H B$ rice husk biochar, $M L B$ maple leaves biochar, $R M$ red mud, $S S$ steel slag, - not significant

* Significant at $p<0.1$

** Significant at $p<0.05$

*** Significant at $p<0.01$

induced a decrease in their phytoavailability following each amendment application.

In agreement with these results, Gray et al. [43] reported an increase in $\mathrm{pH}$, while $\mathrm{RM}$ as an amendment was applied, which induced immobilization of heavy metals in soil and subsequently decreased translocation of metals in the tissues of Festuca Rubra. In addition, Zheng et al. [44] demonstrated that RHB was efficient in an increase of metal immobilization in soil followed by decline in plant accumulation. In contrast to $\mathrm{Cd}, \mathrm{Pb}$, and $\mathrm{Zn}$, a different pattern for $\mathrm{Cu}$ uptake by plant following amendment application was observed. The reason was reported by Kim et al. [45] that the $\mathrm{Cu}$ solubility in soils is primarily governed by (dissolved organic carbon) DOC concentration, rather than soil $\mathrm{pH}$. When soil $\mathrm{pH}$ is above 7.5, so that $\mathrm{Cu}$ solubility increases following DOC concentrations increase and cause an increase in metal uptake by plants [45]. Possessing more organic carbon in RHB caused more $\mathrm{Cu}$ accumulation than MLB-treated soils.

\section{Simple steady-state mass balance model and related input data}

To compare the effectiveness of each treatment on the movement of metals through soil, mass balance method in soil, plant, and leachate phases can be performed. A simple mass balance of heavy metals in soil can be expressed as follows [46]:

$M_{\text {total }}=\left(M_{\mathrm{p}}+M_{\mathrm{f}}+M_{\mathrm{a}}\right)-\left(M_{\mathrm{cr}}+M_{\mathrm{l}}\right)$,

where " $M$ " is the heavy metal, "p" is the parent material, " $\mathrm{a}$ " is the heavy metal from amendment deposition, " $\mathrm{f}$ " is the fertilizer sources, "cr" is crop removal, and " 1 " is the losses by leaching, volatilization, and so forth. After estimating $M_{\text {total }}$, the percentage of each element in each phase was separately calculated. Results of mass balance of heavy metals in soil, plant, and aqueous systems are shown in Table 3. Observations of mass balance indicated high performance of RHB and MLB at 2\% application ratio for all aforementioned metals. In case of $\mathrm{Cd}$, both biochars showed maximum immobilization efficiency rather than inorganic amendments. For stabilizing $\mathrm{Cu}$ in soil, $\mathrm{RM}$ 
Table 3 Results of mass balance of $\mathrm{Cd}, \mathrm{Cu}, \mathrm{Pb}$, and $\mathrm{Zn}$ in soil, plant, and leachate systems according to accumulation percentage (\%)

\begin{tabular}{|c|c|c|c|c|c|c|c|c|c|c|c|c|c|}
\hline \multicolumn{14}{|c|}{ Critical load of heavy metals $(\%)$ under different treatments } \\
\hline $\begin{array}{l}\text { Heavy metals at different } \\
\text { parts }\end{array}$ & Control & $\begin{array}{l}\text { RHB } \\
1\end{array}$ & $\begin{array}{l}\text { RHB } \\
2\end{array}$ & $\begin{array}{l}\text { RHB } \\
3\end{array}$ & $\begin{array}{l}\text { MLB } \\
1\end{array}$ & $\begin{array}{l}\text { MLB } \\
2\end{array}$ & $\begin{array}{l}\text { MLB } \\
3\end{array}$ & RM 1 & RM 2 & RM 3 & SS 1 & SS 2 & SS 3 \\
\hline \multicolumn{14}{|l|}{ Soil } \\
\hline $\mathrm{Cd}$ & 20 & 56 & 63 & 71 & 48 & 63 & 72 & 53 & 59 & 71 & 41 & 46 & 56 \\
\hline $\mathrm{Cu}$ & 65 & 69 & 72 & 74 & 72 & 73 & 76 & 69 & 72 & 75 & 64 & 67 & 69 \\
\hline $\mathrm{Pb}$ & 77 & 94 & 95 & 96 & 94 & 95 & 97 & 94 & 95 & 96 & 95 & 96 & 97 \\
\hline $\mathrm{Zn}$ & 66 & 76 & 79 & 81 & 76 & 77 & 81 & 76 & 77 & 79 & 69 & 71 & 71 \\
\hline \multicolumn{14}{|l|}{ Arial part of plant } \\
\hline $\mathrm{Cd}$ & 80 & 44 & 37 & 29 & 52 & 37 & 28 & 47 & 41 & 56 & 59 & 54 & 45 \\
\hline $\mathrm{Cu}$ & 12 & 11 & 11 & 9 & 10 & 9 & 8 & 11 & 10 & 9 & 9 & 9 & 7 \\
\hline $\mathrm{Pb}$ & 15 & 2 & 2 & 1 & 2 & 1 & 1 & 2 & 2 & 1 & 1 & 1 & 1 \\
\hline $\mathrm{Zn}$ & 15 & 11 & 9 & 8 & 11 & 11 & 9 & 23 & 24 & 31 & 17 & 16 & 19 \\
\hline \multicolumn{14}{|l|}{ Roots } \\
\hline $\mathrm{Cd}$ & - & - & - & - & - & - & - & - & - & - & - & - & - \\
\hline $\mathrm{Cu}$ & 23 & 20 & 17 & 17 & 18 & 18 & 16 & 20 & 18 & 16 & 27 & 24 & 24 \\
\hline $\mathrm{Pb}$ & 8 & 4 & 3 & 3 & 4 & 4 & 2 & 5 & 3 & 3 & 4 & 3 & 2 \\
\hline $\mathrm{Zn}$ & 19 & 13 & 12 & 11 & 13 & 12 & 10 & 14 & 13 & 12 & 14 & 13 & 10 \\
\hline \multicolumn{14}{|l|}{ Leachate } \\
\hline $\mathrm{Cd}$ & 0.20 & 0.03 & 0.02 & 0 & 0.05 & 0.01 & 0 & 0.10 & 0.06 & 0.01 & 0.04 & 0.02 & 0.00 \\
\hline $\mathrm{Cu}$ & 0.03 & 0.01 & 0.00 & 0.03 & 0.01 & 0.01 & 0.01 & 0.01 & 0.01 & 0.004 & 0.01 & 0.01 & 0.002 \\
\hline $\mathrm{Pb}$ & 0.10 & 0.03 & 0.02 & 0.02 & 0.04 & 0.03 & 0.01 & 0.02 & 0.02 & 0.01 & 0.01 & 0.01 & 0.00 \\
\hline $\mathrm{Zn}$ & 0.05 & 0.01 & 0.01 & 0.00 & 0.01 & 0.01 & 0.01 & 0.01 & 0.005 & 0.004 & 0.01 & 0.01 & 0.01 \\
\hline
\end{tabular}

RHB rice husk biochar, $M L B$ maple leaves biochar, $R M$ red mud, $S S$ steel slag (1: $0.5 \%, 2: 1 \%$, and 3: 2\% DW of amendments)

showed high efficiency as well as biochar treatments. The maximum immobilization efficiency for $\mathrm{Pb}$ was observed in MLB- and SS-treated soils. Similar to Cd, both RHB and MLB showed the maximum efficiency to immobilize $\mathrm{Zn}$ in soil. Results demonstrated the ability of root systems to absorb high content of $\mathrm{Cu}$ through soil. The mass balance successfully displayed remediation system within the soil, plant, and leachates.

\section{Chemical speciation of metals}

Assessment of metal speciation and bioavailability in soils using a sequential extraction scheme oftentimes was carried out [13, 47]. In this study, sequential extraction was used to investigate the distribution of metals among different amended soils (Fig. 5). Initially, $\mathrm{Cd}$ existed in a more bioavailable and mobile form than other metals, with more than $50 \%$ of total $\mathrm{Cd}$ exchangeable for some of treatments and control, as well. However, $\mathrm{Cu}, \mathrm{Pb}$, and $\mathrm{Zn}$ were mainly in residual fraction, with very low exchangeable fractions (almost 3, 4, and 3\% of total content, respectively).
The application of soil amendments shifted Cd distributions from residual and exchangeable to carbonate, organic matter, and $\mathrm{Fe}$ and $\mathrm{Mn}$ oxide fractions, especially in $2 \%$ application rate of each amendment (Fig. 5a). The less plant available fractions of $\mathrm{Cd}$ in treated soils were observed in the order of: $2 \%$ of SS $>$ RM $>$ MLB. Results for $\mathrm{Cu}$ indicated a shift from exchangeable to residual and organic bound fractions (Fig. 5b). High content of the P in biochars suggested to being the main reason of an increase in the residual fraction of $\mathrm{Cu}$ in the form of the precipitated $\mathrm{Cu}$ phosphate. It was found that in treated soils, $\mathrm{Pb}$ and $\mathrm{Zn}$ were largely associated with the residual and Fe and Mn oxide fractions and also, to a lesser extent, the carbonate (Fig. 5c, d). Overall, the less exchangeable fractions for $\mathrm{Cd}, \mathrm{Cu}, \mathrm{Pb}$, and $\mathrm{Zn}$ were observed in the order of SS, MLB, $\mathrm{RM}$, and $\mathrm{MLB}=\mathrm{SS}$ treatments, respectively. In other words, the less plant available fractions (exchangeable and carbonate fractions are considered as plant available) for $\mathrm{Cd}, \mathrm{Cu}, \mathrm{Pb}$, and $\mathrm{Zn}$ were achieved in SS (1\%), MLB (2\%)RHB (0.5\%), RM (1\%)-S.S (1\%), and RM (1\%)-MLB $(1 \%)$ treatments, respectively. 

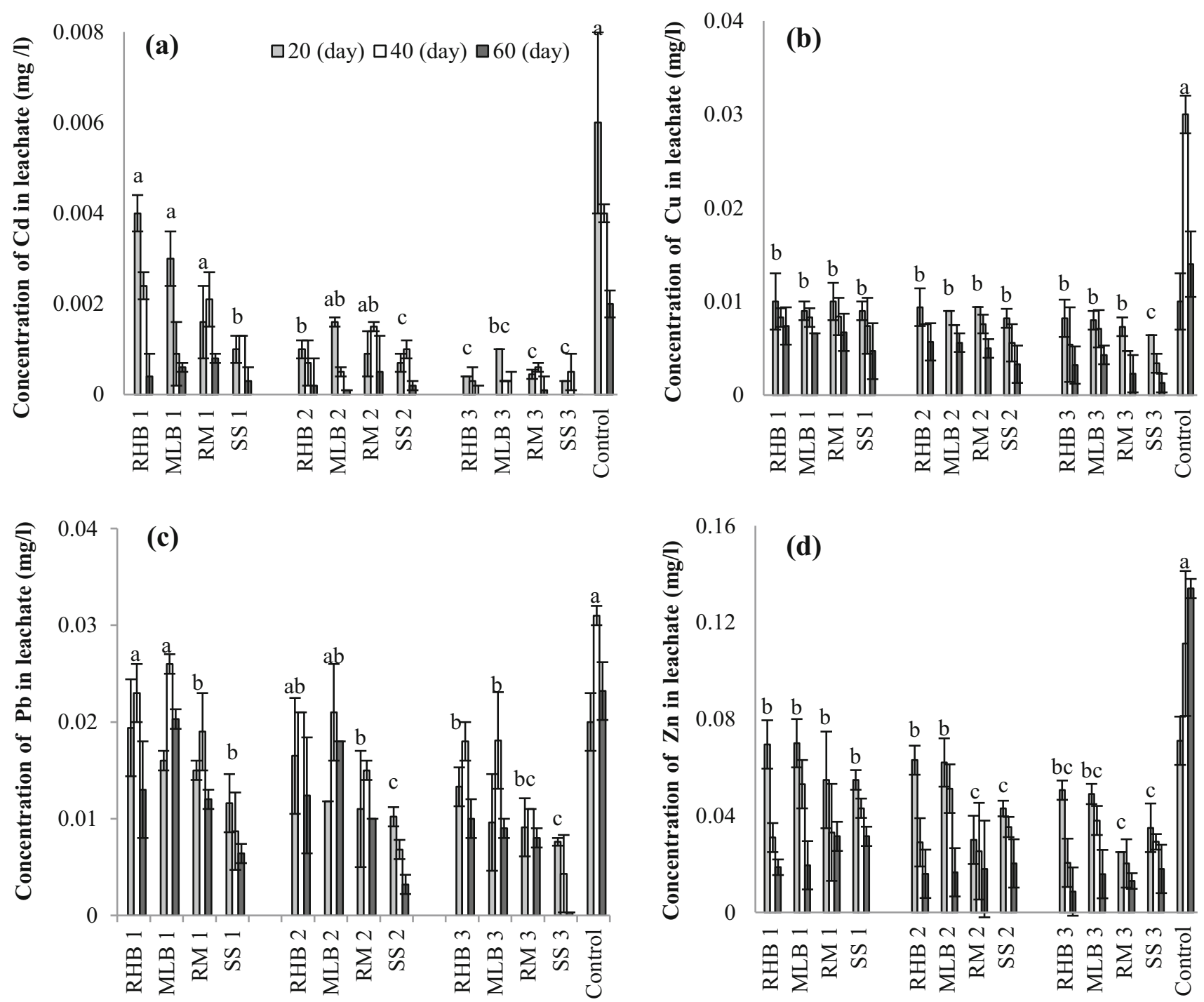

Fig. 3 Mean concentration of heavy metals in leachates for each treatment in three sampling times. (RHB) rice husk biochar, (MLB) maple leaves biochar, $(\mathrm{RM})$ red mud, and (SS) steel slag $(1=0.5 \%$,

\section{Comparison of effectiveness of different treatments}

Table 4 summarizes the results of the effectiveness of different treatments on two metal transfer passages through soil. In this regard, different treatments were divided into two groups which were significantly effective $(\mathrm{O})$ or noteffective (x) on the reduction in reachability and phytoavailability of toxic metals. The total concentrations of $\mathrm{Cd}, \mathrm{Cu}, \mathrm{Pb}$, and $\mathrm{Zn}$ in soil did not change too much when amendments were added. Hence, soil pollution was not impressed by these amendments. Furthermore, $\mathrm{Cd}, \mathrm{Cu}, \mathrm{Pb}$, and $\mathrm{Zn}$ did not respond similarly to the same amendments. This pointed the difficulty out in finding amendments that could be equally effective in multi-element contaminated soils. Although the total metal concentrations in soils could influence metal accumulation in plant tissues, the chemical
$2=1 \%, 3=2 \% \mathrm{DW}$ of amendments). The mean marked with the same letter is not significantly different at $p<0.05(\mathbf{a}: \mathrm{Cd}, \mathbf{b}: \mathrm{Cu}, \mathbf{c}$ : $\mathrm{Pb}$, and $\mathbf{d}: \mathrm{Zn}$ )

fractions of metal in the soils also affected metal uptake by plants. Followed by each treatment, metal fractions varied as a result of chemical reactions between soil particles and amendments. Using different treatments increased immobilization of $\mathrm{Cd}, \mathrm{Cu}, \mathrm{Pb}$, and $\mathrm{Zn}$ at most $62,72,89$, and $66 \%$ by the order of RHB $=$ MLB, and SS amendments ( $2 \%$ application ratio), respectively.

Overall, MLB (2\%) as a novel amendment with the lowapplication ratio turned out to be one of the best compromises in reducing both leaching and phytoavailability of aforementioned metals with a numerous increase in plant biomass results from an increase in soil CEC. Noteworthy, no negative environmental side effect of using biochar or risk on surrounding ecosystem was observed. On the contrary, using RM and SS in high-application dosage could induce not only metal concentration in soil and subsequently their leaching 


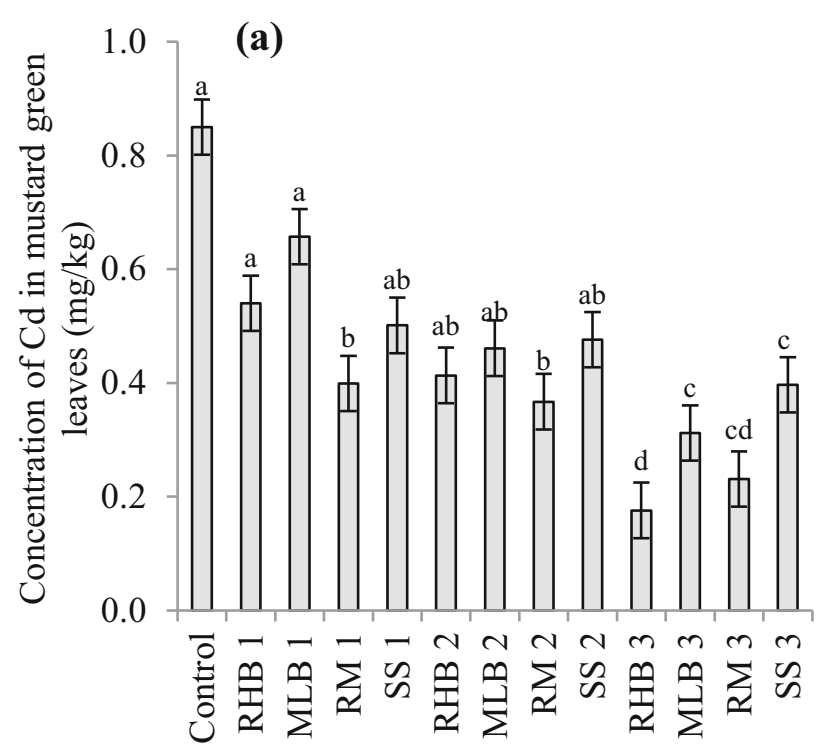

(b)

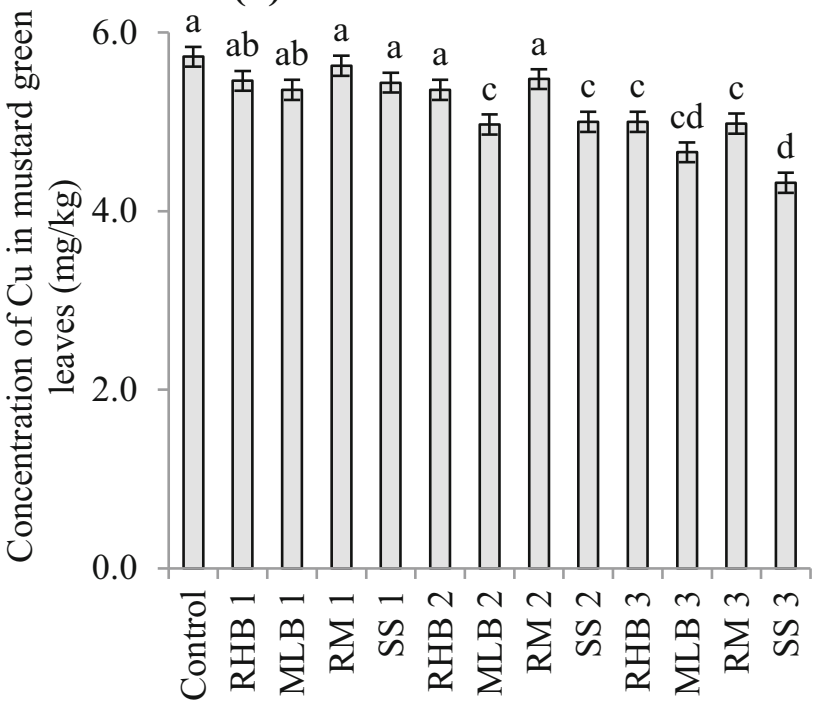

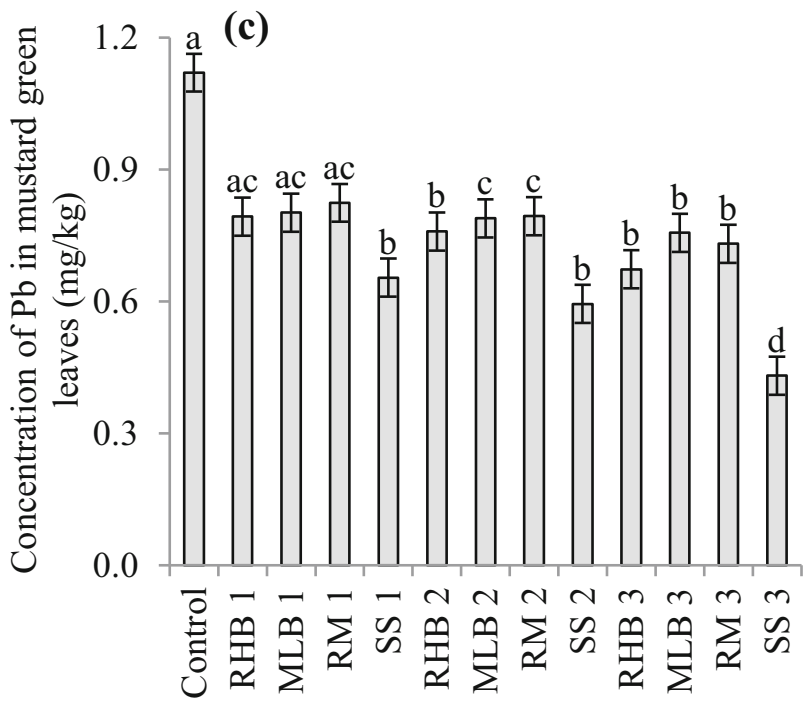

Fig. 4 Concentration of heavy metals in mustard green leaves. (RHB) rice husk biochar, (MLB) maple leaves biochar, (RM) red mud, and (SS) steel slag $(1=0.5 \%, 2=1 \%, 3=2 \%$ dry weight of

and phytoavailability, but also reduction in plant biomass. Therefore, finding the most efficient application dosage of soil amendments is a big concern to manage remediation process in agricultural soils.

\section{Conclusions}

The application of soil amendments that can immobilize heavy metals could provide a cost-effective and sustainable solution for the remediation of contaminated sites. This study addressed to simultaneously controlling both leaching and

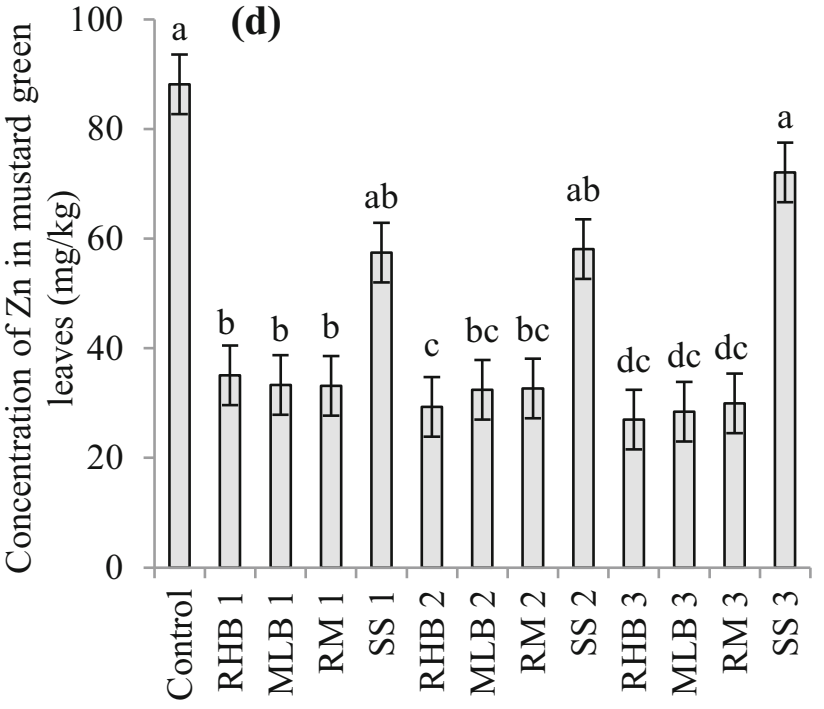

amendments). The mean marked with the same letter is not significantly different at $p<0.05(\mathbf{a}: \mathrm{Cd}, \mathbf{b}: \mathrm{Cu}, \mathbf{c}: \mathrm{Pb}$, and $\mathbf{d}: \mathrm{Zn})$

phytoavailability of $\mathrm{Cd}, \mathrm{Cu}, \mathrm{Pb}$, and $\mathrm{Zn}$ using soil solidification/stabilization technology through several promising amendments. RHB as an abundant agricultural byproduct, with the specific pyrolysis condition, recognized as an effective multi-metal immobilizing amendment. Results indicated that rice husk biochar could be used as a substitution for lime materials to increase the soil $\mathrm{pH}$. In this study, MLB interestingly showed a promising result for the remediation of agricultural soil due to its porous structure, high specific surface area, and mainly its rich nutrients nature. Since most trees are deep-rooted, they absorb minerals from deep in the soil and a good portion of these minerals go into 

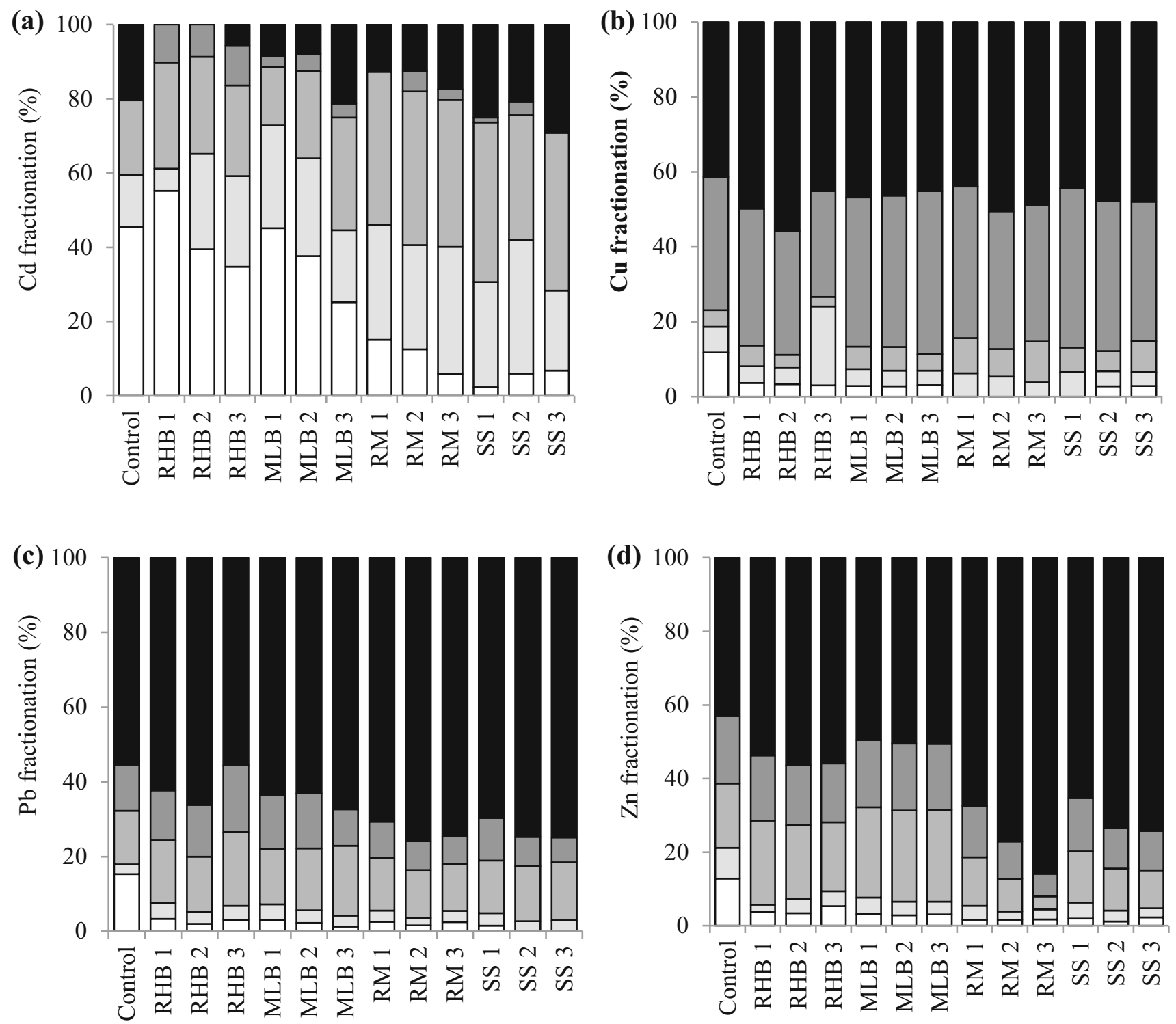

\begin{tabular}{|ll|}
\hline Residual fraction & $\square$ Bound to organic matter \\
$\square$ Bound onto carbonate & $\square$ Exchangable fraction
\end{tabular}

Fig. 5 Distribution of heavy metal fractions in different amended soils. (RHB) rice husk biochar, (MLB) maple leaves biochar, (RM) red mud, and (SS) steel slag $(1=0.5 \%, 2=1 \%, 3=2 \%$ dry weight of amendments) $(\mathbf{a}: \mathrm{Cd}, \mathbf{b}: \mathrm{Cu}, \mathbf{c}: \mathrm{Pb}$, and $\mathbf{d}: \mathrm{Zn})$

the leaves. Therefore, recycling these source of organic matter, through a specific pyrolysis condition, makes biochars high efficient in metal stabilization even in low mixing dosages. Red mud and SS both as inorganic amendments demonstrated favorable results to immobilize metals in soil even in low-application dosages, owing to application of their small particle size.

The results of sequential fractionations provided some evidence of the mechanism of immobilization following soil amendment applications. The application of the biochars suggested an increase in metals associated with carbonate and organic matter. Moreover, RM and SS, due to significantly increasing soil $\mathrm{pH}$, led to an increase in metal precipitation and moved metals into residual fractions. In addition, both RM and SS, which were rich in Fe oxides with reactive surface sites able to bind metals, caused more metals to be associated with the $\mathrm{Fe}$ and $\mathrm{Mn}$ oxide fractions.

According to comparison of the effectiveness of different treatments on two metal transfer pathways through soil, MLB (2\%) recognized as one of the best compromises in reducing both leaching and phytoavailability of metals with no observed decline in plant biomass. Considering 
Table 4 Overview of significant $(p<0.05)$ (o) or not significant (x) effects of treatments on leaching and phytoavailability of heavy metals (at different application ratio of amendments)

\begin{tabular}{|c|c|c|c|c|c|c|c|c|}
\hline \multirow[t]{2}{*}{ Treatments } & \multicolumn{4}{|c|}{ Leaching } & \multicolumn{4}{|c|}{ Phytoavailability } \\
\hline & $\mathrm{Cd}$ & $\mathrm{Cu}$ & $\mathrm{Pb}$ & $\mathrm{Zn}$ & $\mathrm{Cd}$ & $\mathrm{Cu}$ & $\mathrm{Pb}$ & $\mathrm{Zn}$ \\
\hline \multicolumn{9}{|l|}{ RHB (\%) } \\
\hline 0.5 & $\mathrm{x}$ & o & $\mathrm{x}$ & $\mathrm{x}$ & o & $\mathrm{x}$ & $\mathrm{x}$ & $\mathrm{x}$ \\
\hline 1 & $\mathrm{x}$ & o & $\mathrm{x}$ & o & $\mathrm{o}$ & $\mathrm{x}$ & $\mathrm{o}$ & $\mathrm{x}$ \\
\hline 2 & o & $\mathrm{x}$ & 0 & $\mathrm{x}$ & o & o & o & 0 \\
\hline \multicolumn{9}{|l|}{ MLB (\%) } \\
\hline 0.5 & $\mathrm{x}$ & $\mathrm{x}$ & 0 & $\mathrm{x}$ & $\mathrm{x}$ & $\mathrm{x}$ & $\mathrm{x}$ & $\mathrm{x}$ \\
\hline 1 & $\mathrm{x}$ & $\mathrm{o}$ & o & $\mathrm{x}$ & o & $\mathrm{o}$ & $\mathrm{x}$ & $\mathrm{x}$ \\
\hline 2 & $\mathrm{o}$ & $\mathrm{x}$ & o & $\mathrm{x}$ & o & $\mathrm{o}$ & $\mathrm{o}$ & o \\
\hline \multicolumn{9}{|l|}{ RM (\%) } \\
\hline 0.5 & $\mathrm{o}$ & o & o & $\mathrm{x}$ & $\mathrm{o}$ & $\mathrm{x}$ & $\mathrm{x}$ & o \\
\hline 1 & o & o & o & o & o & $\mathrm{x}$ & $\mathrm{x}$ & o \\
\hline 2 & $\mathrm{x}$ & $\mathrm{x}$ & o & $\mathrm{x}$ & $\mathrm{o}$ & $\mathrm{o}$ & $\mathrm{x}$ & o \\
\hline \multicolumn{9}{|l|}{ SS (\%) } \\
\hline 0.5 & $\mathrm{x}$ & o & o & o & o & $\mathrm{x}$ & o & $\mathrm{x}$ \\
\hline 1 & o & o & o & $\mathrm{o}$ & $\mathrm{x}$ & o & o & $\mathrm{x}$ \\
\hline 2 & $\mathrm{x}$ & $\mathrm{x}$ & $\mathrm{o}$ & $\mathrm{x}$ & $\mathrm{o}$ & $\mathrm{o}$ & $\mathrm{o}$ & o \\
\hline
\end{tabular}

$R H B$ rice husk biochar, $M L B$ maple leaves biochar, $R M$ red mud, $S S$ steel slag, $o$ significantly effective, $x$ not significantly effective

environmental management, making biochar from maple leave wastes not only recycled them but also perfectly improved soil properties with the less costs.

The addition of these soil amendments is likely to induce the solidification/stabilization (S/S) of target metals. Therefore, the use of suitable amendments with appropriate dosage not only can reduce the cost of remediation, but also can be helpful in preventing risks for ecosystems. Nonetheless, a number of issues should be considered when soil amendments are applied to improve the efficiency of soil remediation. Furthermore, more research must be done for assessing whether immobilization of contaminants in soil is long enough irreversible to remain stable under natural conditions.

Open Access This article is distributed under the terms of the Creative Commons Attribution 4.0 International License (http://crea tivecommons.org/licenses/by/4.0/), which permits unrestricted use, distribution, and reproduction in any medium, provided you give appropriate credit to the original author(s) and the source, provide a link to the Creative Commons license, and indicate if changes were made.

\section{References}

1. Gaur, A., Adholeya, A.: Prospects of arbuscular mycorrhizal fungi in phytoremediation of heavy metal contaminated soils. Curr. Sci. India 86(4), 528-534 (2004)
2. Adriano, D.C.: Trace elements in the terrestrial environment. Springer, New York (1986)

3. Merrington, G., Alloway, B.J.: The transfer and fate of $\mathrm{Cd}, \mathrm{Cu}$, $\mathrm{Pb}$ and $\mathrm{Zn}$ from historic metalliferous mine sites in the UK. Appl. Geochem. 9, 677-687 (1994)

4. Sengupta, A.: Solidification and Stabilization of Contaminated Soil. Dissertations and theses, university of Orleans (2007)

5. Martin, T.A., Ruby, M.V.: Review of in situ remediation technologies for lead, zinc and cadmium in soil. Remediation 14(3), 35-53 (2004). doi:10.1002/rem.20011

6. Bolan, N.S., Duraisamy, P., Mani, S.: Role of inorganic and organic soil amendments on immobilisation and phytoavailability of heavy metals: a review involving specific case studies. Aust. J. Soil Res. 41(1), 533-555 (2003)

7. Ajmal, M., Rao, R.A.K., Anwar, S., Ahmad, J., Ahmad, R.: Adsorption studies on rice husk: removal and recovery of $\mathrm{Cd}(\mathrm{II})$ from wastewater. Bioresour. Technol. 86(2), 147-149 (2003)

8. Kumar, U., Bandyopadhyay, M.: Sorption of cadmium from aqueous solution using pretreated rice husk. Bioresour. Technol. 97(1), 104-109 (2006)

9. Yamato, M., Okimori, Y., Wibowo, I.F., Anshori, S., Ogawa, M.: Effects of the application of charred bark of Acacia mangium on the yield of maize, cowpea and peanut, and soil chemical properties in South Sumatra, Indonesia. J. Soil Sci. Plant Nutr. 52, 489-495 (2006). doi:10.1111/j.1747-0765.2006.00065.x

10. Tagoe, S.O., Horiuchi, T., Matsui, T.: Effects of carbonized and dried chicken manures on the growth, yield, and $\mathrm{N}$ content of soybean. Plant Soil 306(1), 211-220 (2008)

11. Rodríguez, L., Salazar, P., Preston, T.R.: Effect of biochar and biodigester effluent on growth of maize in acid soils. Livestock Research for Rural Development, Colombia, http://www.lrrd.org/ lrrd21/7/rodr21110.htm (2009). Accessed 1 July 2015

12. Beesley, L., Marmiroli, M.: The immobilization and retention of soluble arsenic, cadmium, and zinc by biochar. Environ. Pollut. 159, 474-480 (2011)

13. Lee, S.H., Lee, J.S., Choi, Y.J., Kim, J.G.: In situ stabilization of cadmium-, lead-, and zinc-contaminated soil using various amendments. Chemosphere 77(8), 1069-1075 (2009)

14. Wong, M.H.: Ecological restoration of mine degraded soils, with emphasis on metal contaminated soils. Chemosphere 50(6), 775-780 (2003)

15. NamKoong, W., Jeong, T.H.: Effect of steel slag addition on immobilization of heavy metal-contaminated soil with phosphate. J. Korea Soc. Waste Manag. 29(8), 769-776 (2012)

16. Tordoff, G.M., Baker, A.J., Willis, A.J.: Current approaches to the revegetation and reclamation of metalliferous mine wastes. Chemosphere 41, 219-228 (2000)

17. Alkorta, I., Hernández-Allica, J., Becerril, J.M., Amezaga, I., Albizu, I., Garbisu, C.: Recent findings on the phytoremediation of soils contaminated with environmentally toxic heavy metals and metalloids such as zinc, cadmium, lead, and arsenic. Rev. Environ. Sci. Biotechnol. J. 3, 71-90 (2004)

18. Mench, M., Vangronsveld, J., Bleeker, P., Ruttens, A., Geebelen, W., Lepp, N.: Phytostabilisation of metal-contaminated sites. In: Morel, J.L., Echevarria, G., Goncharova, N. (eds.) Phytoremediation of Metal-Contaminated Soils, pp. 109-190. Springer, Dordrecht (2006)

19. Madejon, E., de Mora, A.P., Felipe, E., Burgos, P., Cabrera, F.: Soil amendments reduce trace element solubility in a contaminated soil and allow regrowth of natural vegetation. Environ. Pollut. 139(1), 40-52 (2006)

20. Park, J.H., Choppala, G.K., Bolan, N.S., Chung, J.W., Chuasavathi, T.: Biochar reduces the bioavailability and phytotoxicity of heavy metals. Plant Soil 348, 439-451 (2015)

21. MicrotracBEL, Specific surface area and particle size. Seminar on adsorption. Total solution in particle characterization, http:// 
www.nippon-bel.co.jp/tech/seminar06_e.html (2015). Accessed 15 Jan 2015

22. Bouyoucos, G.J.: Directions for making mechanical analysis of soils by the hydrometer method. Soil Sci. 42(3), 225-228 (1936)

23. Thomas, G.W.: Soil pH and soil acidity, In: Sparks, D.L. (ed.) Methods of Soil Analysis, Part 3. Chemical Methods, pp. 475-490. Soil Science Society of America and American Society of Agronomy, Madison (1996)

24. Hesse, P.R.: A Textbook of Soil Chemical Analysis. John Murray Ltd., London (1971)

25. Ure, A.M.: Methods of analysis for heavy metals in soils. In: Alloway, B.J. (ed.) Heavy Metals in Soils, pp. 47-59. Blackie, London (1990)

26. Chen, C.X., Huang, B., Li, T., Wu, G.F.: Preparation of phosphoric acid activated carbon from sugarcane bagasse by mechanochemical processing. BioResources 7(4), 5109-5116 (2012)

27. Tessier, A., Campbell, P.G.C., Bisson, M.: Sequential extraction for the speciation of particulate trace metals. Anal. Chem. 51, 844-851 (1979)

28. Kim, H.S., Kim, K.R., Kim, H.J., Yoon, J.H., Yang, J.E., Ok, Y.S., Owens, G., Kim, K.H.: Effect of biochar on heavy metal immobilization and uptake by lettuce (Lactuca sativa L.) in agricultural soil. Environ. Earth Sci. 74, 1249-1259 (2015)

29. Puga, A.P., Abreu, C.A., Melo, L.C., Beesley, L.: Biochar application to a contaminated soil reduces the availability and plant uptake of zinc, lead, and cadmium. J. Environ. Manag. 159, 86-93 (2015)

30. Jo, I.S., Koh, M.H.: Chemical changes in agricultural soils of Korea: data review and suggested countermeasures. Environ. Geochem. Health 76(2), 105-117 (2004)

31. Beesley, L., Moreno-Jiménez, E., Gomez-Eyles, J.L., Harris, E., Robinson, B., Sizmur, T.: A review of biochars' potential role in the remediation, revegetation and restoration of contaminated soils. Environ. Pollut. 159(12), 3269-3282 (2011)

32. Nejad, Z.D., Kim, J.W., Jung, M.C.: Reclamation of arsenic contaminated soils around mining site using solidification/stabilization combined with revegetation. Geosci. J. 21(3), 385-396 (2017). doi:10.1007/s12303-016-0059-0

33. Liou, T.H.: Preparation and characterization of nanostructured silica from rice husk. Mater. Sci. Eng. 364(1), 313-323 (2004)

34. Radhika, T., Sugunan, S.: Structural and catalytic investigation of vanadia supported on ceria promoted with high surface area rice husk silica. J. Mol. Catal. 250(1-2), 169-176 (2006)

35. Chen, Y., Zhu, Y., Wang, Z., Li, Y., Wang, L., Ding, L., Gao, X., Ma, Y., Guo, Y.: Application studies of activated carbon derived from rice husks produced by chemical thermal process-a review. Adv. Colloid Interface Sci. 163(1), 39-52 (2011)

36. Hong, K.S., Lee, H.M., Bae, J.S., Ha, M.G., Jin, J.S., Hong, T.E., Kim, J.P., Jeong, E.D.: Removal of heavy metal ions by using calcium carbonate extracted from starfish treated by protease and amylase. J. Anal. Sci. Technol. 2, 75-82 (2011)

37. Zhang, Y., Pan, Z.: Characterization of red mud thermally treated at different temperatures. J. Jinan. Univ. Sci. Technol. 19, 293-297 (2005)

38. Chen, H., Sun, H., Li, H.: Effect of heat treatment temperature on cementitious activity of red mud. J. Light Metals 9, 22-25 (2006)

39. Liu, X., Zhang, N., Sun, H., Zhang, J., Li, L.: Structural investigation relating to the cementitious activity of bauxite residuered mud. Cem. Concr. Res. 41(8), 847-853 (2011)

40. Prakongkep, N., Gilkes, R.J., Wiriyakitnateekul, W., Duangchan, A., Darunsontaya, T.: The effects of pyrolysis conditions on the chemical and physical properties of rice husk biochar. Int. J. Mater. Sci. 3(3), 97-103 (2013)

41. Xu, T., Chen, Y., Jong, P., Oterdoom, H., Chang, C.H.: Acer Linnaeus. Flora of China, pp. 493-516. Missouri Botanical Garden and Harvard University Herbaria, Cambridge. http:// www.eflora.org (2012)

42. Park, B.D., Wi, S.G., Lee, K.H., Singh, A.P., Yoon, T.H., Kim, Y.S.: Characterization of anatomical features and silica distribution in rice husk using microscopic and micro-analytical techniques. Biomass Bioenergy 25(3), 319-327 (2003)

43. Gray, C.W., Dunham, S.J., Dennis, P.G., Zhao, F.J., McGrath, S.P.: Field evaluation of in situ remediation of a heavy metal contaminated soil using lime and red-mud. Environ. Pollut. 142(3), 530-539 (2006)

44. Zheng, R.L., Cai, C., Liang, J.H., Huang, Q., Chen, Z., Huang, Y.Z., Arp, H.P.H., Sun, G.X.: The effects of biochars from rice residue on the formation of iron plaque and the accumulation of $\mathrm{Cd}, \mathrm{Zn}, \mathrm{Pb}$, As in rice (Oryza sativa L.) seedlings. Chemosphere 89(7), 856-862 (2012)

45. Kim, K.R., Kim, J.G., Park, J.S., Kim, M.S., Owens, G., Youn, G.H., Lee, J.S.: Immobilizer-assisted management of metalcontaminated agricultural soils for safer food production. J. Environ. Manag. 105, 88-95 (2012)

46. Alloway, B.J.: Heavy metals in soils. In: Lindholm, T., Heikkilä, R., Heikkilä, M. (eds.) Ecosystems, Fauna and Flora of the Finnish-Russian Nature Reserve Friendship, The Finnish Environment. Nature and Natural Resources 124. Springer, Berlin (1995)

47. Jung, M.C., Thornton, I.: Environmental contamination and seasonal variation of metals in soils, plants and waters in the paddy fields around a $\mathrm{Pb}-\mathrm{Zn}$ mine in Korea. Sci. Total Environ. 198(2), 105-121 (1997)

\section{Publisher's Note}

Springer Nature remains neutral with regard to jurisdictional claims in published maps and institutional affiliations. 